\title{
CLOACAL GLAND RESPONSE TO PREGNANT MARE'S SERUM GONADOTROPHIN IN CHICKEN $\times$ QUAIL HYBRIDS
}

\author{
PATRICIA SARVELLA \\ United States Department of Agriculture, ARS, \\ Animal Science Research Division, Beltsville, Maryland 20705, U.S.A.
}

(Received 7th October 1970, revised 4th December 1970)

Intergeneric crosses between Dark Cornish chicken males and Japanese quail, Coturnix coturnix japonica, females have not been reported to exhibit an enlargement of the cloacal gland as in male Japanese quail (Pl. 1, Fig. 1A), but are similar to the chicken male (Pl. 1, Fig. 1B). These hybrids are all males (Bammi, Shoffner \& Haiden, 1966), but are sterile (Ogasawara \& Abplanalp, 1968).

In the male chicken, the secondary sexual characters, especially comb development, responded to increased androgen production by the testes and to injections of PMSG (Dorfman, Dorfman \& Grim, 1948; Breneman, 1951; Snedecor, 1968). Male Japanese quails responded to the increased androgen by an increase in testis size and enlargement of the cloacal glands (Sachs, 1967). Injections with pregnant mare's serum gonadotrophin (PMSG) were started to see if the sterility of the hybrids could be influenced.

Daily injections of $100,150,200$, or 300 i.u. PMSG were injected i.m. into the legs of the hybrids, from 3 months of age for 6 weeks, or 150 i.u. PMSG were injected daily from hatching to 3 months of age. Many hybrids died during the 1st week when the injections were given from the time of hatching. Testis sizes were measured, and one or both testes removed. Cytological sections (both paraffin-wax and squash) were prepared. If large enough, the testis was divided in half and one-half was fixed in 3 parts alcohol: 1 part acetic acid and squashed in acetocarmine. The other half was used for paraffin-wax embedded sections, fixed in Bouin's fluid, and stained with haematoxylin and eosin. If the testis was too small to divide, one testis was used for paraffin-wax sections and one for squashing. The testes were graded on a scale of 1 (no development of tubules, unorganized gonad or ovotestis) to 8 (large tubules with mature spermatozoa) according to the amount of cytological development.

The first effect noted was an enlargement of the cloacal gland of fifteen injected hybrids (Pl. 1, Fig. 1C, centre and right), but not in the controls (Pl. 1, Fig. 1C, left). Sections of the cloacal glands without any external cloacal development had short epithelial cells and small lumina and resembled those of the chicken. Hybrids with enlarged cloacal areas had larger and more convoluted lumina and longer epithelial cells. Sections of the cloacal gland in the reproductive male Japanese quail, showed large lumina and long epithelial cells. With a decline in reproduction, these lumina shrank and the epithelial 
cells were shorter. The hybrids resembled the reproductive Japanese quail but the cloacal area was not as large.

Hybrids with enlarged cloacal glands had larger and more advanced testes (Table 1). The only testes in the hybrids to show development of primary spermatocytes were those in which injections had started at the time of hatching, or regenerated testes from injected birds. A small amount of secretion was obtained from the hybrids with the enlarged cloacal glands. No spermatozoa were observed. Wilcox \& Clark (1961) also reported a clear fluid but no spermatozoa from the hybrids after PMSG injections, but did not report enlargement of the cloacal glands or testes.

\section{TABLE 1}

EXTERNAL APPEARANCE OF THE GLOAGAL GLAND IN GHIGKEN $\times$ QUAIL HYBRIDS IN RELATION TO TESTIS SIZE AND DEVELOPMENT

\begin{tabular}{|c|c|c|c|}
\hline & $\begin{array}{l}\text { Cloacal gland } \\
\text { rudimentary }\end{array}$ & $\begin{array}{l}\text { Cloacal gland } \\
\text { small }\end{array}$ & $\begin{array}{l}\text { Cloacal gland } \\
\text { medium to large }\end{array}$ \\
\hline $\begin{array}{l}\text { Control } \\
\text { No. of birds } \\
\text { No. of testes } \\
\text { Testis length } \\
\text { Testis width } \\
\text { Development* }\end{array}$ & $\begin{array}{c}7 \\
10 \\
3 \cdot 5 \pm 0 \cdot 8 \\
2 \cdot 3 \pm 0 \cdot 3 \\
1 \text { to } 4\end{array}$ & $\begin{array}{l}0 \\
0 \\
0 \\
0 \\
0\end{array}$ & $\begin{array}{l}0 \\
0 \\
0 \\
0 \\
0\end{array}$ \\
\hline $\begin{array}{l}\text { PMsG injected at } 3 \text { months age for } 6 \text { weeks } \\
\text { No. of birds } \\
\text { No. of testes } \\
\text { Testis length } \\
\text { Testis width } \\
\text { Development* }\end{array}$ & $\begin{array}{c}9 \\
11 \\
4 \cdot 3 \pm 0 \cdot 7 \\
2 \cdot 4 \pm 0 \cdot 4 \\
1 \text { to } 4\end{array}$ & $\begin{array}{c}4 \\
7 \\
8 \cdot 0 \pm 1 \cdot 0 \\
5 \cdot 8 \pm 0 \cdot 5 \\
3 \text { to } 4\end{array}$ & $\begin{array}{c}4 \\
6 \\
12 \cdot 2 \pm 1 \cdot 6 \\
7 \cdot 3 \pm 1 \cdot 7 \\
3 \text { to } 5\end{array}$ \\
\hline $\begin{array}{l}\text { PMSG injected from hatching to } 2 \text { to } 3 \text { months old } \\
\text { No. of birds } \\
\text { No. of testes } \\
\text { Testis length } \\
\text { Testis width } \\
\text { Development* }\end{array}$ & $\begin{array}{c}12 \\
24 \dagger \\
2 \cdot 5 \pm 0 \cdot 3 \\
1 \cdot 8 \pm 0.2 \\
2 \text { to } 5\end{array}$ & $\begin{array}{c}4 \\
8 \dagger \\
3 \cdot 9 \pm 1 \cdot 0 \\
2 \cdot 6 \pm 0 \cdot 4 \\
2 \text { to } 5\end{array}$ & $\begin{array}{c}5 \\
10 \dagger \\
10 \cdot 5 \pm 1 \cdot 5 \\
5 \cdot 6 \pm 0 \cdot 8 \\
1 \text { to } 6 \neq\end{array}$ \\
\hline
\end{tabular}

* Range in stages of development.

$\uparrow$ Variation in size between two testes of the same bird.

\$ Also, possible neoplastic type present.

The PMSG injections increased the size of the cloacal gland but not the testis in four hybrids, i.e. those birds with small cloacal glands with continuous injections from the time of hatching. In sparrows given testosterone propionate, Pfeiffer (1947) found that the testes had to be over $2.0 \mathrm{~mm}$ in diameter to be responsive.

The PMSG only appears to be effective in stimulating spermatogenesis in actively growing testes, since the gonads from birds injected from the time of hatching and those from birds in which the testes regenerated were the only ones in which the spermatogenic cells were seen to undergo meiotic division. The PMSG probably acted by stimulating testis development with resulting production of androgens which influenced the formation of the cloacal gland. On removal of one gonad, the cloacal gland was observed to regress in size. When 

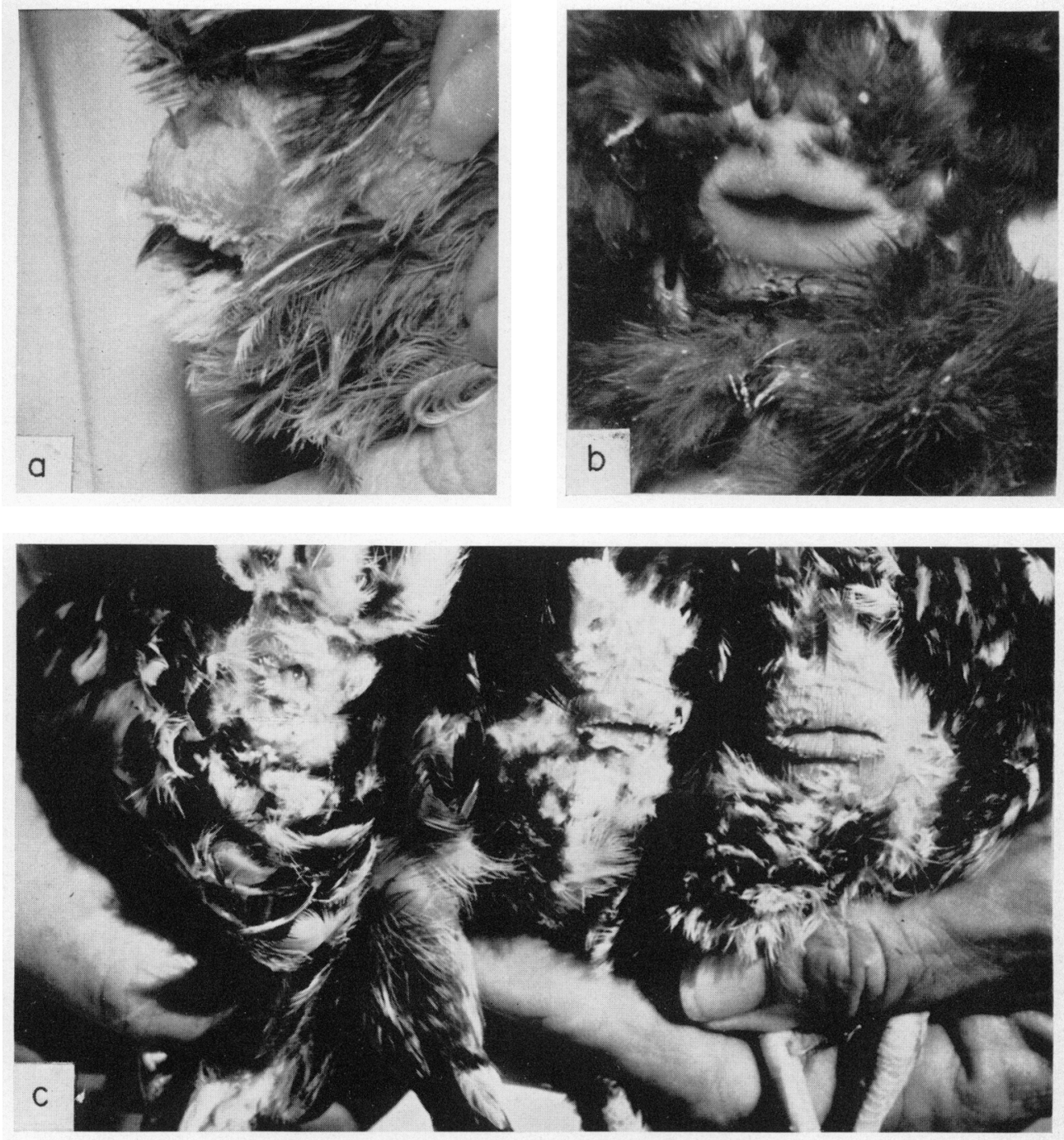

Cloaral glands. A Male lapanese quail; (B) mak chicken; (C) injected chicken $x$ quail hybrids: lefi-ne crilargenent of glands like the controls, cemere medium sion gland. righe large gland. 
both gonads were removed for histological study, the cloacal gland completely disappeared.

In addition to enlargement of the testes, PMSG appeared to stimulate oviduct development. Control birds had one or two very small oviducts. Six PMSGtreated birds had considerable development of one or both oviducts. These could measure up to $55 \mathrm{~cm}$ long. Three oviducts were filled with a fluid which was probably responsible for the secretions rather than the cloacal gland.

About one-half of the injected chicken $\times$ quail hybrids had a bump in the comb region but it did not appear to be related to testis size nor to the injections. Such hybrids were expressing the secondary sexual character from the male quail rather than the male chicken.

Thus, PMSG injections into these intergeneric hybrids affected the development of some testes and stimulated a secondary sexual characteristic, i.e. the cloacal gland as in the male Japanese quail, but not the comb as in the rooster. The time of injection appeared to be important. Cloacal development can be used as an external indicator of testis development in intergeneric hybrids.

I thank Mr Melvin Gehman for his technical assistance. The discussions with Dr H. Opel were greatly appreciated. Dr E. F. Godfrey graciously examined my slides and verified the conclusions.

\section{REFERENCES}

Bamm, R. K., Shoffner, R. N. \& Hamen, G. J. (1966) Sex ratios and karyotype in the chickenCoturnix quail hybrid. Can. F. Genet. Cytol. 8, 533.

BRENEMAN, W. R. (1951) A factorial analysis of pituitary-gonad-comb relationships in the chick. Poult. Sci. 30, 231.

Dorfman, R. I., Dormman, A. S. \& Grim, D. (1948) Studies on the bioassay of hormones-the assay of pregnant mares' serum chorionic gonadotrophin. Endocrinology, 42, 93.

Ogasamara, F. X. \& Abplanalp, H. (1968) Light and electron microscopic studies of the gonad of the chicken-quail hybrid. Poult. Sci. 47, 1703.

Preifrer, C. A. (1947) Gonadotrophic effects of exogenous sex hormones on the testes of sparrows. Endocrinology, 41, 92.

SAcrs, B. D. (1967) Photoperiodic control of the cloacal gland of the Japanese quail. Science, N.Y. 157, 201.

SNEDECOR, J, G. (1968) Response of testis and comb of the radiothyroidectomized chick to PMs. Poult. Sci. 47, 148.

Wircox, F. H. \& Clark, C. E. (1961) Chicken-quail hybrids. F. Hered. 52, 167. 